\title{
Real-time monitoring of proton exchange membrane fuel cell stack failure
}

\author{
Billy $\mathrm{Wu}^{1}$ (1) Michael A. Parkes ${ }^{2} \cdot$ Luca de Benedetti $^{3} \cdot$ Andrew J. Marquis $^{3}$ • \\ Gregory J. Offer ${ }^{3} \cdot$ Nigel P. Brandon ${ }^{2}$
}

Received: 27 March 2016/ Accepted: 25 July 2016

(C) The Author(s) 2016. This article is published with open access at Springerlink.com

\begin{abstract}
Uneven pressure drops in a 75-cell 9.5-kWe proton exchange membrane fuel cell stack with a U-shaped flow configuration have been shown to cause localised flooding. Condensed water then leads to localised cell heating, resulting in reduced membrane durability. Upon purging of the anode manifold, the resulting mechanical strain on the membrane can lead to the formation of a pin-hole/membrane crack and a rapid decrease in open circuit voltage due to gas crossover. This failure has the potential to cascade to neighbouring cells due to the bipolar plate coupling and the current density
\end{abstract}

heterogeneities arising from the pin-hole/membrane crack. Reintroduction of hydrogen after failure results in cell voltage loss propagating from the pin-hole/membrane crack location due to reactant crossover from the anode to the cathode, given that the anode pressure is higher than the cathode pressure. Through these observations, it is recommended that purging is avoided when the onset of flooding is observed to prevent irreparable damage to the stack.

\section{Graphical Abstract}
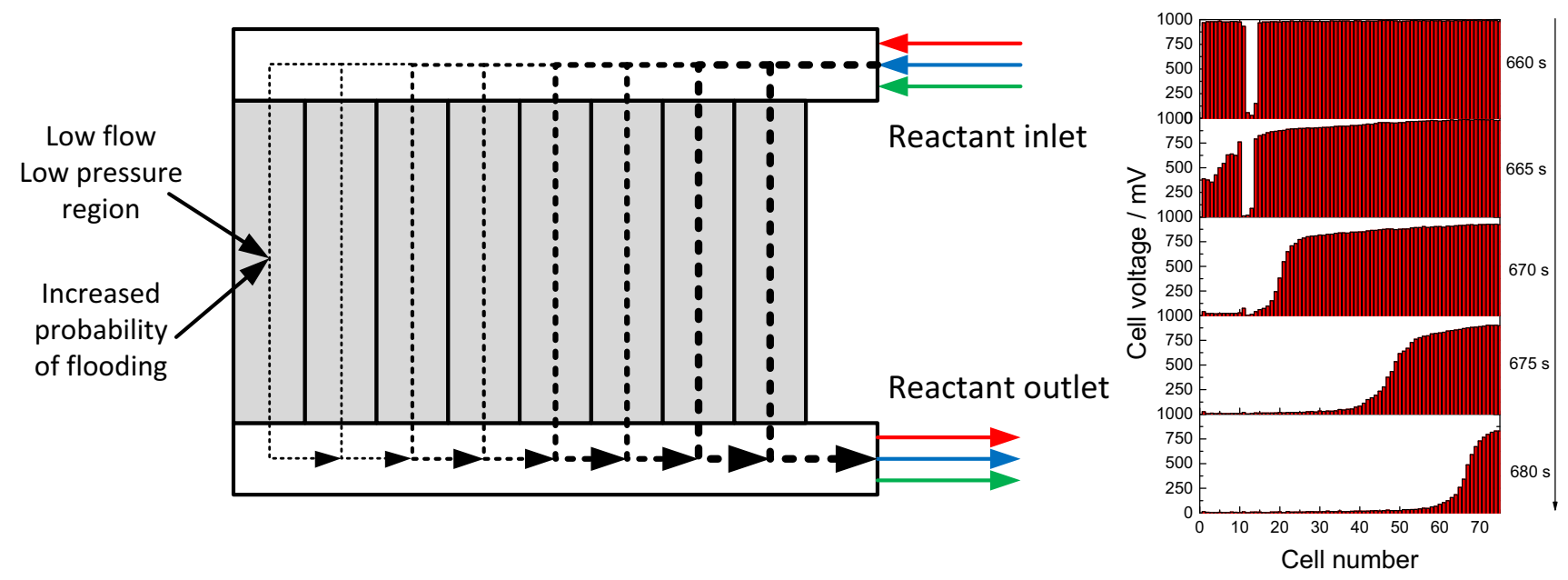

Billy Wu

billy.wu@imperial.ac.uk

1 Dyson School of Design Engineering, Imperial College London, London, UK

2 Department of Earth Science and Engineering, Imperial College London, London, UK

3 Department of Mechanical Engineering, Imperial College London, London, UK

Keywords Proton exchange membrane fuel cell . Pin-hole $\cdot$ Failure $\cdot$ Flooding $\cdot$ Purging $\cdot$ Cell voltage monitoring

\section{Introduction}

Fuel cells (FCs) are electrochemical devices that convert chemical fuels into electrical energy with efficiencies greater than direct combustion. Of the different varieties of 
FCs, low-temperature proton exchange membrane fuel cells (PEMFCs) have received the greatest attention, with respect to automotive applications, as a possible replacement for the internal combustion engine (ICE) [1]. PEMFCs are now commercially available; however, further improvements in durability must be made, especially under conditions which represent real-world conditions, to increase adoption. Addressing the issue of durability, the United States Department of Energy has stated that in order for FC systems to compete with ICEs, lifetimes of more than $5000 \mathrm{~h}$ with less than a $10 \%$ loss in performance need to be achieved [2].

Durability can be broadly divided into two categories: gradual degradation and abrupt failure. The mechanisms generally acknowledged as contributing towards gradual degradation include membrane thinning and cracking [3-5], catalyst layer degradation [6-10] and degradation of the gas diffusion layers (GDLs) [8, 11]. An extensive review of degradation mechanisms can be found in a number of review papers $[4,7,11,12]$. Stack failure can arise from a number of mechanisms including pin-hole formation [5, 13], ice formation $[14,15]$ and flooding $[14,16]$, the causes of these are often linked and a function of their operating conditions which are made worse in automotive scale systems due to heterogeneities resulting from the stack design. Uneven pressure drops, for example, can result in heterogeneous distributions of reactants and the accumulation of water within the FC stack [17]. This effect is exasperated in automotive stacks operating at high current densities. It follows that reactant heterogeneity caused by uneven pressure drops is dependent on the stack configuration with the most prevalent designs being the reverse flow (U shape) and parallel flow ( $\mathrm{Z}$ shape). Z-shaped stacks typically offer a more even reactant distribution at the cost of reduced volumetric power density [18-21].

Heterogeneous distributions of reactants within the FC stack can lead to uneven mass transport losses and the degradation of the membrane electrode assembly (MEA) through membrane thinning, while the localised build-up of water on the FC MEA results in droplet formation in the flow fields of the bipolar plates [22]. Water build-up can eventually lead to cell flooding and the formation of hotspots which can cause the formation of pin-holes, a major cause of FC failure [23]. The importance of anode and cathode purging has been highlighted in a number of publications [24-26]. Anode purging in particular has been critically identified as being needed for removal of water and nitrogen, which has crossed over from the cathode. Most of these works, however, focus mainly on optimising cell performance and fuel utilisation [27-30] rather than report about the possible failure effects of purging which can arise from mechanical strain on the membrane, which have been suggested by some authors but not extensively reported [28].
Pin-hole formation leads to internal gas leaks between the anode and the cathode resulting in a loss of stack performance, which has frequently been reported on the single cell level in the academic literature [13]. However, as highlighted by Santis et al. [31], current and therefore voltage heterogeneities in the cells of a PEMFC stack can affect adjacent cells due to the high electrical conductivity of the bipolar plates, with the failure of one cell often inducing changes in neighbouring cells. To understand the nature of pin-hole formation and the coupled behaviour of multiple cells together, investigations of full-scale stacks in real time are required, which is rarely reported in the literature.

Post-mortem open circuit voltage (OCV) monitoring has been used by several authors to identify failed cells within a stack, details of which have been used to characterise pinholes [22, 23, 32], whilst others have used segmented single cells to investigate differences in the current density in the presence of a pin-hole [13]. Commonly, small stacks of $5-18$ cells are studied [33,34]; however, studies on automotive systems containing hundreds of cells are rarely reported.

Here we report the real-time observation of complete stack failure which we propose is due to pin-hole/membrane crack formation in a 75-cell 9.5-kWe PEMFC U-shaped stack. Using cell voltage monitoring (CVM) techniques and pressure measurements, we observe how the voltage of individual cells changes in response to variable load and gas management strategies such as purging. We observe that anode purging, a control technique used to remove nitrogen crossover and water, coupled with flooding, can potentially lead to the formation of pin-hole/membrane cracks, which has been suggested in the literature but not reported with real-time measurements leading to the failure. Thus far, the academic literature has focused on performance optimisation with regard to purging; however, we highlight the importance of considering the possible failure modes this can aggravate. We are then able to correlate this failure to heterogeneous reactant distributions caused by the U-shaped stack design. These observations allow us to propose a new control technique which could prevent similar stack failures.

\section{Experimental set-up}

A Nedstack P9.5-75 PEMFC stack was used in this study. This stack is rated to $9.5 \mathrm{kWe}$ with 75 cells, liquid cooling and an active surface area of $200 \mathrm{~cm}^{2}$. The experimental set-up is based on the work previously reported by $\mathrm{Wu}$ et al. [35, 36]. The Nedstack P9.5-75 has a U-shaped stack configuration where the air, hydrogen and cooling inlets/ outlets are on the same side. Figure 1a shows the diagram 

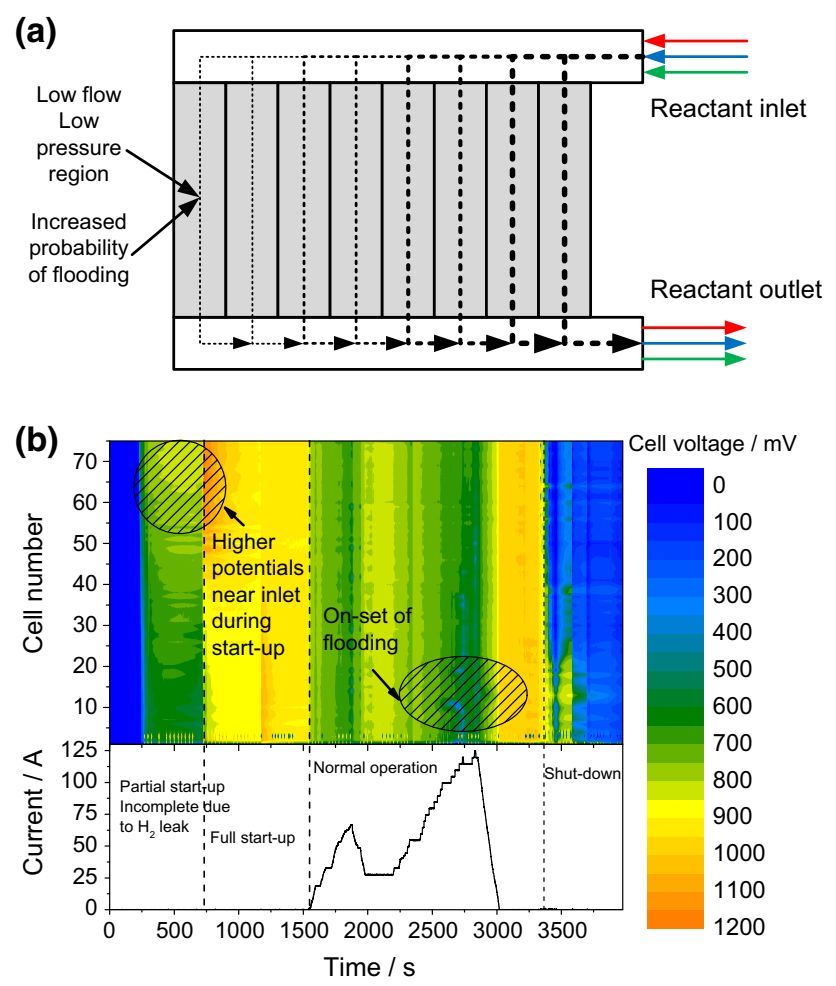

Fig. 1 a Diagram of a U-shaped stack reactant configuration and b cell voltages and stack current during test 1 of a 9.5-kWe PEMFC stack

of a U-shaped stack reactant configuration highlighting the uneven pressure drops resulting from the design, with cells furthest from the inlet/outlet of the stack having the highest pressure drop. This will result in cells furthest from the stack inlet/outlets having lower reactant flow than cells closest to the inlets.

\section{Stack flooding and failure}

Figure $1 \mathrm{~b}$ shows the 75-cell voltages of a 9.5-kWe PEMFC stack during initial testing with the reactant inlet/outlets both near cell number 75 . Here the anode was operated in a dead-ended mode with an inlet pressure of $100 \mathrm{kPa}$ at $\mathrm{OCV}$ and a purge frequency of $30 \mathrm{~s}$ with a $0.5 \mathrm{~s}$ opening time. The cathode blower was operated under zero-back pressure mode with an operating stoichiometry in excess of 10 . It can be seen that, upon introduction of hydrogen, the cell potentials increase rapidly. However, this increase is not uniform, with cells nearest the inlet/outlets rising first due to pressure drop effects. During normal operation, it can be seen that at higher currents, cell potentials become increasingly non-uniform with regions deeper in the U-shaped stack exhibiting lower cell voltages. The cause of this is likely due to the difficulty in removing liquid water from cells further from the inlet/outlets due to the uneven pressure drops. Upon observation of the falling cell voltage, the load was removed and the stack shut down. It should also be noted that the instantaneous oscillations observed in cells $1-5$ are due to localised sampling noise in the data acquisition device, which periodically and instantaneously causes a measured voltage change before returning to the as-expected voltage value. This sampling noise however does not impact the performance of the stack nor the conclusions drawn from it.

Figure $2 \mathrm{a}$ shows the cell voltages during a test that took place $24 \mathrm{~h}$ after the initial test shown in Fig. 1b when cell voltage heterogeneities were observed. Here testing conditions were the same as in the initial test. It can be seen that $1496 \mathrm{~s}$ into the test, cells 11-13 experienced an abrupt drop in potential. Prior to failure, this region was exhibiting higher overpotentials, possibly indicating flooding, as the
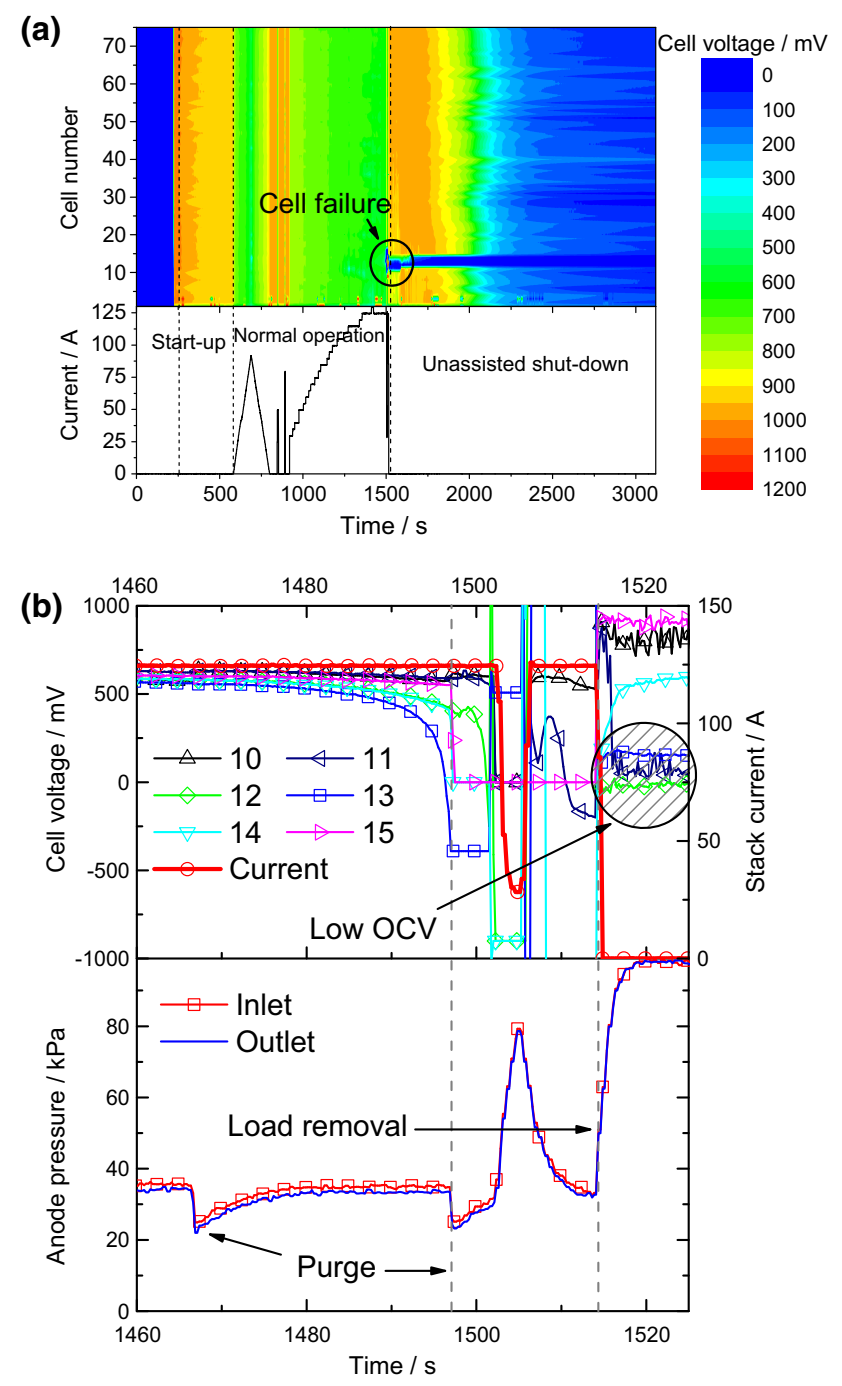

Fig. 2 a Cell voltages and stack current during test 2 of a 9.5-kWe PEMFC stack with failure event and $\mathbf{b}$ cell voltages $10-15$ around the pin-hole and anode pressure during pin-hole formation 
formation of liquid water on the GDL would result in increased mass transport losses due to limited gas diffusion. The failure occurred in the same location as the low cell voltages in the initial test. After the fall in cell voltage was observed, the load was removed from the FC, the hydrogen supply closed and an unassisted shutdown was performed. In this case, an external load was not applied, which is normally applied to consume all remaining hydrogen in the GDL and gas manifolds due to the fault. At the point of failure, the inlet/outlet temperatures were, respectively, 58 and $65{ }^{\circ} \mathrm{C}$ for air and 23 and $24{ }^{\circ} \mathrm{C}$ for hydrogen. Both inlet and outlet relative humidity for air and hydrogen were measured as near/fully saturated. Both anode and cathode were operated with external humidification as detailed in $\mathrm{Wu}$ et al. $[35,36]$.

Closer inspection of the cells near the failure point is shown in Fig. 2b. Under constant current conditions, cell 13 exhibited a rapid drop in potential suggesting a flooding event. Upon application of a purge event (defined by the control programme as every $30 \mathrm{~s}$ ), as denoted by the abrupt pressure fluctuations, the cell voltage profile varied significantly, with negative potentials observed in cells 11-13. At a time step of $1502 \mathrm{~s}$, stack current fluctuated due to the resistive load bank voltage limitation of $0 \mathrm{~V}$ and the decaying stack voltage. Upon removal of the load, the OCV of cells 11-13 remained low, suggesting pin-hole/ membrane crack formation. The cell voltage of neighbouring cells exhibited an irregular instability, likely caused by the uneven reaction current density normally observed near a pin-hole [13] and the coupling between adjacent cells [31]. The proposed cause of this was localised flooding due to uneven pressure drops, leading to localised hotspots and weakening of the membrane. Upon application of an anode purge event, this is thought to have caused mechanical stress on the MEA resulting in its mechanical failure and the formation of a pin-hole/membrane crack. The voltage in cell 14 after load removal follows the trend in the anode pressure, suggesting that prior to failure there was hydrogen undersupply in that cell. Thus, with load removal and an increase in anode pressure the cell voltage recovered as hydrogen diffused back into the cell. The fact that the cells that failed were not the deepest within the stack could potentially be due to a difference in the thermal and flow conditions in those cells. Here it is expected that the end cells will cool and that the flow conditions will be impacted by the end of the air/ hydrogen manifold.

These observations lead us to propose a control system where, if a flooding event is observed, anode purging is prohibited in order to avoid irreparable damage to the PEMFC through mechanical stressing of a thermally weakened membrane.

\section{Pin-hole/membrane crack diagnosis}

In order to diagnose the stack after the failure event, hydrogen was introduced and the OCV was monitored in a subsequent test $24 \mathrm{~h}$ after the pin-hole/membrane crack formation, with Fig. 3 showing the cell potentials, anode pressure and anode flow rate of the 75-cell stack. Here the air flow rate was fixed to $140 \mathrm{~L} / \mathrm{min}$ with the anode in either dead-ended or open-ended modes. It can be seen that, upon introduction of hydrogen with the anode openended, all cell potentials reach an OCV of approximately $1 \mathrm{~V}$, apart from cells 11-13 which have been identified as the source of the pin-hole/membrane crack. Subsequently, when the anode is dead-ended and the pressure increases, cells neighbouring the pin-hole/membrane crack drop in potential to $0 \mathrm{~V}$ extremely rapidly. Cells closer to the reactant inlets subsequently gradually drop in potential with this effect cascading from the location of the pin-hole/ membrane crack. Once the anode pressure had reached a steady state, indicating that the manifolds have filled with hydrogen, the flow meter indicates a steady flow. This therefore suggests that hydrogen is crossing over from the anode to the cathode due to the pin-hole/membrane crack, since the anode is in a dead-ended mode. Upon opening of the hydrogen solenoid, the pressure of the anode decreases and cell voltages (apart from 11 to 13) increase back to an OCV of approximately $1 \mathrm{~V}$. The possible cause of the potential drop is attributed to the crossover of hydrogen from the anode to the cathode from the pin-hole resulting in a hydrogen-hydrogen system and therefore no potential difference being generated. Hydrogen crosses over from the anode to the cathode rather than the other way around as the anode pressure is higher than the cathode pressure. Recovery is observed when the anode pressure is reduced when opening the purge valve due to balancing of the anodic and cathodic pressures, reducing crossover.

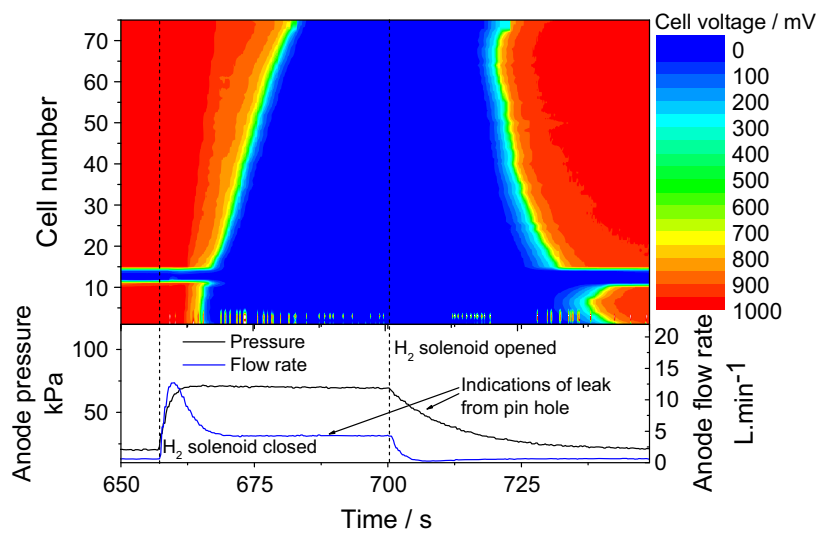

Fig. 3 Cell voltages, anode pressure and anode flow rate of a 75-cell 9.5-kWe PEMFC after pin-hole formation when opening and closing the hydrogen outlet solenoid under no load 


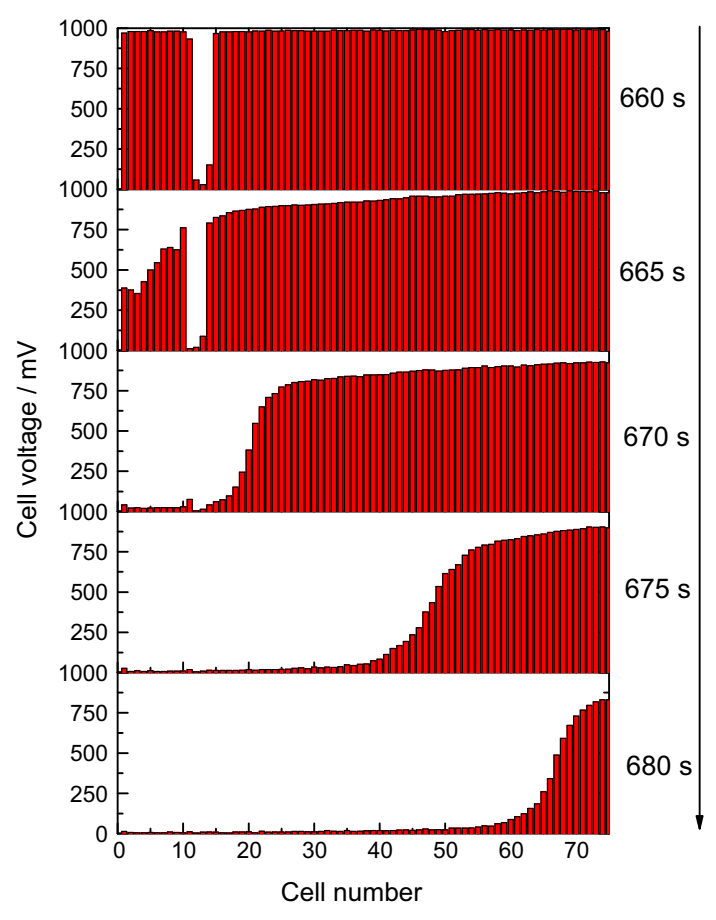

Fig. 4 Bar chart plot of cell voltages during in a 75-cell stack after pin-hole formation and anode pressurisation

Figure 4 shows the cell voltages at a time step of $660 \mathrm{~s}$ in 5 -s increments to visualise this effect more clearly. At a time step of $660 \mathrm{~s}$, the anode compartment is at near ambient pressure as the anode solenoid is open. All cell voltages are at approximately $1 \mathrm{~V}$, apart from the failed cells. Upon closing of the anode solenoid, hydrogen pressure increases to $70 \mathrm{kPa}$ and the cells immediately downstream from the pin hole towards the end of the stack decay in potential. The decay in cell potential then propagates to other cells, taking approximately $40 \mathrm{~s}$ to propagate to all cells after pressurising the anode. Hydrogen crossover from the anode to the cathode is the likely cause of this, resulting in a potential difference of $0 \mathrm{~V}$ in the eventual $\mathrm{H}_{2} / \mathrm{H}_{2}$ cell. The observed trends support the proposed pin-hole/membrane crack theory, which, whilst not $100 \%$ conclusive, is highly likely.

Alternatively, a crack in the graphite bipolar plates could also result in gas crossover and the observed low $\mathrm{OCV}$ and cascading failure. However, this is unlikely since there was no external mechanical impulse, which could have caused this beyond the anode purge which the authors believe could not be of a sufficient magnitude to cause a crack in the graphite plate.

\section{Conclusions}

Uneven pressure drops in large PEMFC stacks have been shown to cause failure which we propose is due to localised flooding, leading to hotspots. The resulting decrease in mechanical strength of the membrane due to the localised heating, compounded with an anode purge event inducing mechanical strain, can lead to the formation of pin-hole/ membrane cracking. The high electronic conductivity of the bipolar plates means that current and therefore potential heterogeneities can cascade to neighbouring cells. The resulting pin-hole/membrane crack, under modest anode pressures, causes neighbouring cells to decrease in OCV due to the crossover of hydrogen from anode to cathode. This reduces the oxygen partial pressure in the cathode resulting in a zero net cell voltage. These observations suggest that when a flooding event is observed, purging should be avoided to prevent possible pin-hole/membrane crack formation. To our knowledge, this is the first time pin-hole/membrane crack formation has been reported in real time for an automotive scale PEMFC system. This work highlights that possible failure modes need to be considered when developing an anode purge control scheme, not just focusing on performance optimisation as is commonly reported in the academic literature.

Acknowledgments The authors would like to thank Richard Silversides for assistance with advice on the electric systems and previous fuel cell development team members: Mardit Matian, Ralph Clague, Mark Cordner, Sam Tippets, Ed Spofforth-Jones, Alana Johnson, Laura Harito, Charles Banner-Martin, Akash Agrawal, Matthew Wong, Dan-Fung Chan, Tanya Chong, Omar Al Fakir, Nicolas Lee, Robert Bilinski, Nicolas Higginson, Rebecca Nelson, Michael Squire, Ashwin Suguna-Balan, Ryan Williams, Jignesh Patel, Olivia Tillbert, Adya Jha, Xin Miao, Nasrin Shahed Khah, Felix Vesper, Christian Wirsching and Sven Veismann. The authors would also like to acknowledge the EPSRC for funding this work, through a Career Acceleration Fellowship for Gregory Offer, award number EP/ I00422X/1, as well as the in-kind contributions from Johnson Matthey, Nedstack, BOC, Domel, Sensirion, National Instruments, Swagelok and RS.

Open Access This article is distributed under the terms of the Creative Commons Attribution 4.0 International License (http://crea tivecommons.org/licenses/by/4.0/), which permits unrestricted use, distribution, and reproduction in any medium, provided you give appropriate credit to the original author(s) and the source, provide a link to the Creative Commons license, and indicate if changes were made.

\section{References}

1. Pollet BG, Staffell I, Shang JL (2012) Current status of hybrid, battery and fuel cell electric vehicles: from electrochemistry to market prospects. Electrochim Acta 84:235-249. doi:10.1016/j. electacta.2012.03.172

2. US DOE (2013) US Drive: fuel cell technical team roadmap

3. Huang X, Solasi R, Zou Y, Feshler M, Reifsnider K, Condit D et al (2006) Mechanical endurance of polymer electrolyte membrane and PEM fuel cell durability. J Polym Sci Part B Polym Phys 44:2346-2357. doi:10.1002/polb.20863

4. de Bruijn FA, Dam VAT, Janssen GJM (2008) Review: durability and degradation issues of PEM fuel cell components. Fuel Cells 8:3-22. doi:10.1002/fuce.200700053 
5. Matsuura T, Chen J, Siegel JB, Stefanopoulou AG (2013) Degradation phenomena in PEM fuel cell with dead-ended anode. Int J Hydrog Energy 38:11346-11356. doi:10.1016/j.ijhydene. 2013.06.096

6. Shao-Horn Y, Ferreira P, Morgan D, Gasteiger HA, Makharia R (2006) Coarsening of $\mathrm{Pt}$ nanoparticles in proton exchange membrane fuel cells upon potential cycling. ECS Trans 1:185-195. doi:10.1149/1.2214553

7. Wu J, Yuan XZ, Martin JJ, Wang H, Zhang J, Shen J et al (2008) A review of PEM fuel cell durability: degradation mechanisms and mitigation strategies. J Power Sour 184:104-119. doi:10. 1016/j.jpowsour.2008.06.006

8. Silva RA, Hashimoto T, Thompson GE, Rangel CM (2012) Characterization of MEA degradation for an open air cathode PEM fuel cell. Int J Hydrog Energy 37:7299-7308. doi:10.1016/j. ijhydene.2011.12.110

9. Franck-Lacaze L, Bonnet C, Choi E, Moss J, Pontvianne S, Poirot $\mathrm{H}$ et al (2010) Ageing of PEMFC's due to operation at low current density: investigation of oxidative degradation. Int $\mathbf{J}$ Hydrog Energy 35:10472-10481. doi:10.1016/j.ijhydene.2010. 07.180

10. Dubau L, Castanheira L, Chatenet M, Maillard F, Dillet J, Maranzana $G$ et al (2014) Carbon corrosion induced by membrane failure: the weak link of PEMFC long-term performance. Int J Hydrog Energy 39:21902-21914. doi:10.1016/j.ijhydene. 2014.07.099

11. Park J, Oh H, Ha T, Lee Y, Min K (2015) A review of the gas diffusion layer in proton exchange membrane fuel cells: durability and degradation. Appl Energy 155:866-880. doi:10.1016/j. apenergy.2015.06.068

12. Zhang S, Yuan X-Z, Hin JNC, Wang H, Friedrich KA, Schulze M (2009) A review of platinum-based catalyst layer degradation in proton exchange membrane fuel cells. J Power Sour 194:588-600. doi:10.1016/j.jpowsour.2009.06.073

13. Lin R, Gülzow E, Schulze M, Friedrich K (2011) Investigation of membrane pinhole effects in polymer electrolyte fuel cells by locally resolved current density. J Electrochem Soc 158:11. doi:10.1149/1.3504255

14. Ous T, Arcoumanis C (2013) Degradation aspects of water formation and transport in proton exchange membrane fuel cell: a review. J Power Sour 240:558-582. doi:10.1016/j.jpowsour.2013. 04.044

15. Mishler J, Wang Y, Mukherjee PP, Mukundan R, Borup RL (2012) Subfreezing operation of polymer electrolyte fuel cells: ice formation and cell performance loss. Electrochim Acta 65:127-133. doi:10.1016/j.electacta.2012.01.020

16. Li H, Tang Y, Wang Z, Shi Z, Wu S, Song D et al (2008) A review of water flooding issues in the proton exchange membrane fuel cell. J Power Sour 178:103-117. doi:10.1016/j.jpowsour. 2007.12.068

17. Liu H, Li P (2013) Maintaining equal operating conditions for all cells in a fuel cell stack using an external flow distributor. Int $\mathrm{J}$ Hydrog Energy 38:3757-3766. doi:10.1016/j.ijhydene.2013.01. 022

18. Chang PAC, St-Pierre J, Stumper J, Wetton B (2006) Flow distribution in proton exchange membrane fuel cell stacks. J Power Sour 162:340-355. doi:10.1016/j.jpowsour.2006.06.081

19. Koh J-H, Seo H-K, Lee CG, Yoo Y-S, Lim HC (2003) Pressure and flow distribution in internal gas manifolds of a fuel-cell stack. J Power Sour 115:54-65. doi:10.1016/S0378-7753(02)00615-8

20. Baschuk JJ, Li X (2004) Modelling of polymer electrolyte membrane fuel cell stacks based on a hydraulic network approach. Int J Energy Res 28:697-724. doi:10.1002/er.993
21. Park J, Li X (2006) Effect of flow and temperature distribution on the performance of a PEM fuel cell stack. J Power Sour 162:444-459. doi:10.1016/j.jpowsour.2006.07.030

22. Niroumand AM, Pooyanfar O, Macauley N, DeVaal J, Golnaraghi $F$ (2015) In-situ diagnostic tools for hydrogen transfer leak characterization in PEM fuel cell stacks part I: R\&D applications. J Power Sour 278:652-659. doi:10.1016/j.jpowsour. 2014.12.093

23. Tian G, Wasterlain S, Endichi I, Candusso D, Harel F, François X et al (2008) Diagnosis methods dedicated to the localisation of failed cells within PEMFC stacks. J Power Sour 182:449-461. doi:10.1016/j.jpowsour.2007.12.038

24. Strahl S, Husar A, Riera J (2014) Experimental study of hydrogen purge effects on performance and efficiency of an open-cathode proton exchange membrane fuel cell system. J Power Sour 248:474-482. doi:10.1016/j.jpowsour.2013.09.122

25. Meyer Q, Ashton S, Curnick O, Reisch T, Adcock P, Ronaszegi $\mathrm{K}$ et al (2014) Dead-ended anode polymer electrolyte fuel cell stack operation investigated using electrochemical impedance spectroscopy, off-gas analysis and thermal imaging. J Power Sour 254:1-9. doi:10.1016/j.jpowsour.2013.11.125

26. Wang Y, Basu S, Wang C-Y (2008) Modeling two-phase flow in PEM fuel cell channels. J Power Sour 179:603-617. doi:10.1016/ j.jpowsour.2008.01.047

27. Chen Y-S, Yang C-W, Lee J-Y (2014) Implementation and evaluation for anode purging of a fuel cell based on nitrogen concentration. Appl Energy 113:1519-1524. doi:10.1016/j.ape nergy.2013.09.028

28. Kim YS, Kim S, Lee nw, Kim ms (2015) Study on a purge method using pressure reduction for effective water removal in polymer electrolyte membrane fuel cells. Int J Hydrog Energy 40:9473-9484. doi:10.1016/j.ijhydene.2015.05.136

29. Chen J, Siegel JB, Stefanopoulou AG, Waldecker JR (2013) Optimization of purge cycle for dead-ended anode fuel cell operation. Int J Hydrog Energy 38:5092-5105. doi:10.1016/j. ijhydene.2013.02.022

30. Jang J-H, Yan W-M, Chiu H-C, Lui J-Y (2015) Dynamic cell performance of $\mathrm{kW}$-grade proton exchange membrane fuel cell stack with dead-ended anode. Appl Energy 142:108-114. doi:10. 1016/j.apenergy.2014.12.073

31. Santis M, Freunberger SA, Papra M, Wokaun A, Büchi FN (2006) Experimental investigation of coupling phenomena in polymer electrolyte fuel cell stacks. J Power Sour 161:1076-1083. doi:10.1016/j.jpowsour.2006.06.007

32. Tian G, Wasterlain S, Candusso D, Harel F, Hissel D, François X (2010) Identification of failed cells inside PEMFC stacks in two cases: anode/cathode crossover and anode/cooling compartment leak. Int J Hydrog Energy 35:2772-2776. doi:10.1016/j.ijhydene.2009.05.015

33. Stumper J, Rahmani R, Fuss F (2010) Open circuit voltage profiling as diagnostic tool during stack lifetime testing. J Power Sour 195:4928-4934. doi:10.1016/j.jpowsour.2009.12.061

34. Ashraf Khorasani MR, Asghari S, Mokmeli A, Shahsamandi MH, Faghih Imani B (2010) A diagnosis method for identification of the defected cell(s) in the PEM fuel cells. Int J Hydrog Energy 35:9269-9275. doi:10.1016/j.ijhydene.2010.04.157

35. Wu B, Parkes MA, Yufit V, De Benedetti L, Veismann S, Wirsching $C$ et al (2014) Design and testing of a $9.5 \mathrm{kWe}$ proton exchange membrane fuel cell-supercapacitor passive hybrid system. Int J Hydrog Energy 39:7885-7896. doi:10.1016/j.ijhy dene.2014.03.083

36. Wu B, Matian M, Offer GJ (2012) Hydrogen PEMFC system for automotive applications. Int $\mathrm{J}$ Low-Carbon Technol 7:28-37. doi:10.1093/ijlct/ctr026 